\title{
SPECIES DISTRIBUTION MODELING OF THE CASPIAN WHIPSNAKE DOLICHOPHIS CASPIUS (SQUAMATA: SERPENTES): A TOOL FOR RANKING CONSERVATION PRIORITIES IN THE WESTERN PONTIC STEPPE
}

\begin{abstract}
A prediction (Maxent) has been made of the potential distribution of the Caspian whipsnake (Dolichophis caspius) within the Western Pontic steppe (exemplified by Ukraine and the Crimea) for conservation purposes. Ranking has been accomplished of conservation priorities amongst administrative units in the area with the view of alerting local government officials and nature conservation practitoners on the species and tracking consequences of climate change. Refs 21. Figs 1. Tables 2.Keywords: Dolichophis caspius, Serpentes, Western Pontic steppe, species distribution modeling, nature conservation, ranking conservation priorities.

B. М. Тumaр, О.Д. Некрасова

\section{МОДЕЛИРОВАНИЕ РАСПРОСТРАНЕНИЯ ЖЕЛТОБРЮХОГО ПОЛОЗА DOLICHOPHIS CASPIUS (SQUAMATA: SERPENTES) В ЗАПАДНО-ПОНТИЙСКОЙ СТЕПИ: ИНСТРУМЕНТ ДЛЯ РАНЖИРОВАНИЯ ПРИОРИТЕТНЫХ ТЕРРИТОРИЙ ДЛЯ ОХРАНЫ ОКРУЖАЮЩЕЙ СРЕДЫ}

\begin{abstract}
Институт зоологии НАН Украины, Украина, 01601, Киев, ул. Б. Хмельницкого, 15; vtytar@gmail.com, oneks@mail.ru

Прогноз (Maxent) по возможному распространению Dolichophis caspius в Западно-Понтийской степи (на примере Украины и Крыма) был сделан с целью его сохранения. Ранжирование приоритетных участков для охраны редкого вида было выполнено среди административно-территориальных единиц с целью получения ценной информации для оповещения должностных лиц местного самоуправления и министерства по охране окружающей среды, а также отслеживания последствий изменения климата. Библиогр. 21 назв. Ил. 1. Табл. 2.

Ключевые слова: Dolichophis caspius, змеи, Западная Понтийская степь, моделирование распространения видов, охрана природы, ранжирование приоритетных территорий.
\end{abstract}

\section{Introduction}

This paper focuses on the potential distribution of Dolichophis caspius (Gmelin, 1789) (Hierophis caspius) and aims to find ecological conditions that determine its distribution, particularly in areas of the Western Pontic Steppe (exemplified by Ukraine and the Crimea).

In general, the range of the species stretches from the Balkans to west Kazakhstan [1]. The snake inhabits primarily forest-steppe and steppe habitats in lowlands, being often confined to areas alongside water courses [2].

According to European conservation legislation, D. caspius is in need of strict protection (Habitats Directive 92/43/EEC). Also, the Ukrainian Red Data Book lists the species as vulnerable [3]; the species is considered as well in Annex №3 of the Red Data Book of the Russian Federation [4]. The snake is often a victim of road mortality or direct persecution and suffers from habitat loss, so a good perspective on the extent and quality of its distribution range can lead to more efficient management plans and conservation actions,

Schmalhausen Institute of Zoology NAS of Ukraine, 15, vul. B. Khmel'nytskogo, Kyiv, 01601, Ukraine; vtytar@gmail.com, oneks@mail.ru.

(c) Санкт-Петербургский государственный университет, 2016 
and support planned monitoring activity targeting the species, especially in the light of economic growth and global climate change.

Focusing on Ukraine and the Crimea, we attempt to predict the potential distribution of D. caspius within the area (and various administrative units) by using species distribution models (SDMs). Species distribution modeling has attracted much research attention over the last decade (for an overview see Research Fronts 2014...) [5]. SDMs predict the potential distribution of a species by interpolating identified relationships between presence/absence or presence-only data of a species on one hand and environmental predictors on the other hand across an area of interest. The accuracy of an SDM, therefore, highly depends on the environmental predictors that are used to model a species' distribution or habitat suitability and should capture the ecological niche of a species. From the array of various applications, Maxent [6] stands out in terms of predictive performance [7-8].

\section{Materials and methods}

Species records. The used dataset consisted of 582 georeferenced point records from the home range of the species, including 268 from Ukraine and the Crimea from data of Sahlean et al. (2014) [9] and other records from the Pontic Steppe ([10-12] and O. D. Nekrasova, unpublished data).

Sampling bias was reduced by the OccurrenceThinner [13]. After thinning the dataset consisted of 412 records.

Bioclimatic data. To relate the occurrence records of D.caspius with abiotic conditions, we downloaded the 19 bioclimatic variables from the WorldClim database at a 5 arcmin resolution [14].

Statistical modeling. To avoid multicollinearity, we assessed the patterns of intercorrelation among the potential environmental controls by a Principal Components Analysis (PCA) on their correlation matrix. Variables were grouped according to whether they loaded strongly on the rotated PCA axes 1,2 or 3 .

Maxent distribution model. We used the default settings of Maxent in this study. We ran models with 50 bootstrap replicates, and assessed model performance using the average AUC (area under the receiver operating curve) score to compare model performance. AUC values $>0.9$ are considered to have 'very good', $>0.8$ 'good' and $>0.7$ 'useful' discrimination abilities [15]. The logistic output format was used, where suitability values range from 0 (lowest suitability) to 1 (highest suitability). Results were processed and visualized in DIVA-GIS 7.5.

Anthropogenic impact. The 'Human Footprint' (Wildlife Conservation Society (WCS), \& Center for International Earth Science Information Network (CIESIN)/Columbia University (2005) [16] was accounted for to evaluate the extent of human influences within areas predicted to be suitable for D. caspius. It score ranges from zero to 100 .

\section{Results and discussion}

In the multivariate analysis (Table 1) the first three Principal Components accounted for $85.1 \%$ of the variance in the data set.

The first factor (PCA 1) accounted for $56.6 \%$ of the environmental variation and most likely reflects the significant (direct or indirect, a question yet to be resolved) dependence 
Table 1. Bioclimatic variables and their loadings on the first three axes of a Principal Components

\begin{tabular}{|l|c|c|c|c|}
\hline \multicolumn{1}{|c|}{ Variable } & Acronym & PCA axis 1 & PCA axis 2 & PCA axis 3 \\
\hline Mean Monthly Temperature Range & bio2 & 0.122 & -0.055 & $\mathbf{0 . 9 6 8}$ \\
\hline Max Temperature of Warmest Month & bio5 & 0.196 & $\mathbf{0 . 7 8 7}$ & 0.454 \\
\hline Mean Temperature of Warmest Quarter & bio10 & 0.179 & $\mathbf{0 . 8 9 8}$ & -0.051 \\
\hline Annual Precipitation & bio12 & $\mathbf{0 . 9 1 9}$ & -0.185 & 0.130 \\
\hline Precipitation of Wettest Month & bio13 & $\mathbf{0 . 9 0 2}$ & 0.198 & 0.069 \\
\hline Precipitation of Driest Month & bio14 & 0.007 & $-\mathbf{0 . 9 2 8}$ & 0.063 \\
\hline Precipitation of Wettest Quarter & bio16 & $\mathbf{0 . 9 1 3}$ & 0.177 & 0.069 \\
\hline Precipitation of Driest Quarter & bio17 & 0.068 & $-\mathbf{0 . 9 1 7}$ & 0.062 \\
\hline Precipitation of Warmest Quarter & bio18 & -0.057 & $-\mathbf{0 . 8 2 5}$ & -0.019 \\
\hline Precipitation of Coldest Quarter & bio19 & $\mathbf{0 . 8 5 7}$ & 0.247 & 0.121 \\
\hline Eigenvalue & & 10.8 & 3.5 & 1.9 \\
\hline \% of total variance & 56.6 & 18.3 & 10.1 \\
\hline \% of cumulative variance & 56.6 & 75.0 & 85.1 \\
\hline
\end{tabular}

N o t e. Marked in bold correlations are > 0.70; non-significant variables have been excluded from the table.

of the species on moisture conditions predetermined by the Annual Precipitation (bio12), strongly correlated with bio13, bio16 and bio19. PCA 1 scores were significantly and negatively correlated with the longitude $\left(\mathrm{r}_{\mathrm{PCA} 1}=-0.4104, \mathrm{p}<0.05\right)$, meaning an East-West variation related to variables associated with precipitation.

On the contrary, PCA 2 ( $18.3 \%$ of the total variance) positively focuses on temperature conditions, particularly on the significantly inter-correlated Maximum Temperature of Warmest Month (bio5) and Mean Temperature of Warmest Quarter (bio10) versus the pleiad of bio14, bio17 and bio18. PCA 3 contributes to a fairly moderate amount of variance (around 10\%) and specifically focuses on the Mean Monthly Temperature Range (bio2). Both PCA 2 and PCA 3 are significantly and negatively correlated with latitude $\left(\mathrm{r}_{\mathrm{PCA}} 2=\right.$ $-0.4035, \mathrm{p}<0.05$ and $\left.\mathrm{r}_{\mathrm{PCA} 3}=-0.1733, \mathrm{p}<0.05\right)$, meaning an indication of a North-South gradient associated with temperature variables.

The strong influence of precipitation and temperature found in the present study is in accord with previous findings [17-18]. For instance, it was found that for the snakes and lizards in Texas the environmental variable which correlated most highly with the Detrended Correspondence Analysis (DCA) first axis was mean annual precipitation (in our case, bio12). The second DCA axis was most strongly correlated with temperature variables and was interpreted as "a north-south gradient of decreasing mean annual temperature, increasing rigor of winter cold and increasing seasonality of temperature" [17].

In similar modeling projects, highly correlated variables often are removed from sets of predictors. However, Elith et al. (2011) [19] found that even in the presence of correlated variables Maxent performs better than most other modeling methods, thus all described covariates were retained for the final model. Nevertheless, we tested a customized set of all 20 possible 3-variable models and compared their AUCs with the AUC of the full model, incorporating all 19 bioclimatic variables. Although the AUC across all models was very high (AUC $>0.8$ ), the full model significantly outperformed the others: 0.934 against $0.833, \mathrm{p}<0.05$ ), so it has been chosen to model the distribution of D. caspius in the study area (Figure).

The better understanding of the potential distribution of D.caspius within areas adjacent to its northern range limit provides a perspective, useful for increasing the 


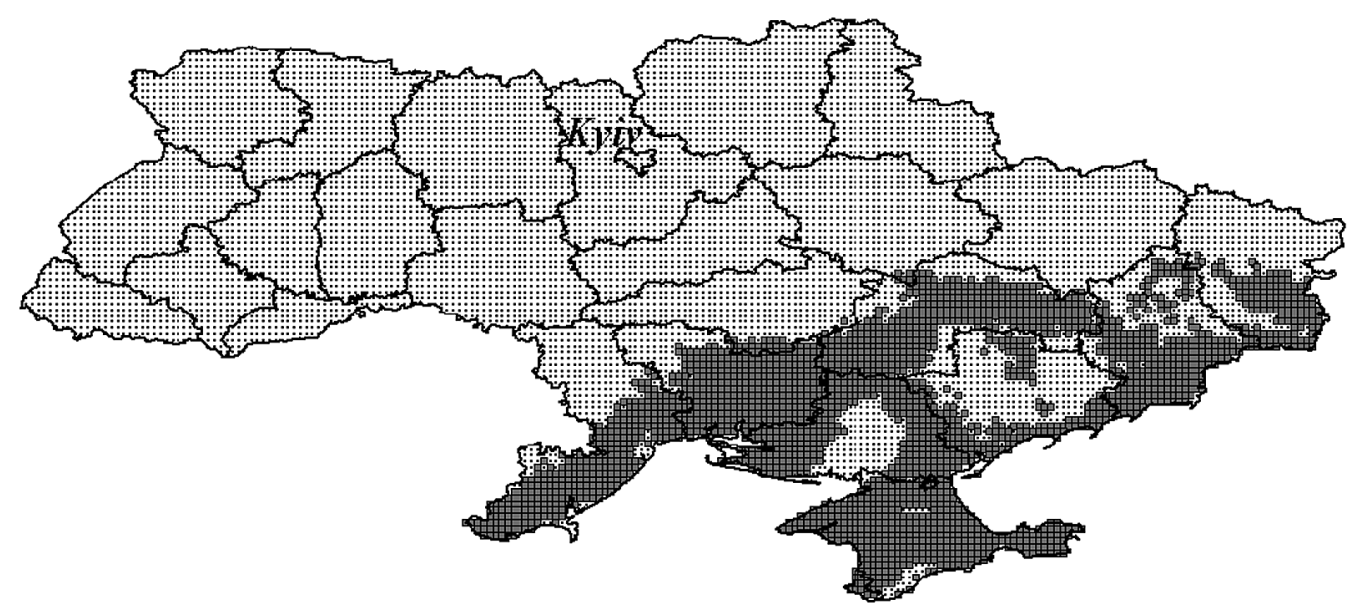

Mapping result of the maximum entropy niche modeling of the home range of the Caspian Whipsnake (D. caspius) in Ukraine and the Crimea: areas with the probability of presence of the species $\geq 50 \%$ are shaded in dark gray.

probability of detecting this species in the field, identifying conservation sites and also in selecting new sites for reintroduction of the species into its natural habitat. However, only $22 \%$ of the area predicted to be suitable for the snake possess a probability of presence of the species exceeding an arbitrary $50 \%$ threshold. Therefore, the ranking of conservation priorities amongst administrative units with the view of alerting local government officials and nature conservation practioners on the species can be seen as one of the first steps towards guided planning of conservation and research efforts (Table 2).

In terms of the average probability of presence of D. caspius $\geq 50 \%$, four administrative units are of particular interest, namely Mykolayiv, Crimea (in conjunction with Sevastopol), Luhansk and Odesa. Amongst these units the Crimea occupies the largest portion (18.1\%) of the study area. Next to the Crimea are Odesa (13.2\%) and Mykolayiv (12.8\%), and to a much lesser extent Luhansk (6.1\%).

Very few areas are predicted to be occupied by the species in Kirovohrad, Kharkiv and Poltava units (0.2-1.0\%). Expanses of these units border the northern limits of the home range of D. caspius and contemporary bioclimatic conditions here seem to be less suitable for the snake. Nevertheless, the establishment of edge populations in these areas cannot be excluded. Compared with populations near the core of a species' range, edge populations tend to be characterized by low density and high temporal variation, so it may be difficult in such places to discover them in the field. Given the evidence that modern climate change is reshuffling the geographic distributions of plant and animal species world-wide [20], the discovery and subsequent montoring of such populations (D. caspius, seen as a model species) can be considered an important research issue for tracking consequences of climate change.

Within the study area of predicted D. caspius presence $\geq 50 \%$ the human impact (i.e. the 'Human Footprint' scores) consisted an average of $43.9 \pm 0.3$. This is just slightly below the average computed from the species' point data scattered across the entire home range: $46.1 \pm 0.9$. However for some considered administrative units the average scores are higher, meaning a greater human impact on the environment and probably poorer conditions for the snake, but not in the Crimea. These particular units are Kherson (49.2), 
Table 2. Administrative units in Ukraine and the Crimea, ranked according to the size of the area where the average probability of presence of D. caspius $\geq 50 \%$ and to the average score of the Human Footprint

\begin{tabular}{|l|c|l|c|l|c|}
\hline $\begin{array}{c}\text { Administrative } \\
\text { Unit }\end{array}$ & $\begin{array}{c}\text { Average } \\
\text { probability } \\
\text { of presence } \\
\mathbf{2 5 0} \%\end{array}$ & $\begin{array}{c}\text { Administrative } \\
\text { Unit }\end{array}$ & $\begin{array}{c}\text { \% of area with } \\
\text { the probability } \\
\text { of presence } \\
\mathbf{2 5 0} \%\end{array}$ & $\begin{array}{c}\text { Administrative } \\
\text { Unit }\end{array}$ & $\begin{array}{c}\text { Average score } \\
\text { of Human } \\
\text { Footprint }\end{array}$ \\
\hline Mykolayiv & 0.634 & Crimea & 18.1 & Poltava & 38.5 \\
\hline Crimea & 0.630 & Dnipropetrovsk & 16.1 & Crimea & 39.5 \\
\hline Luhansk & 0.611 & Kherson & 13.2 & Kirovohrad & 39.9 \\
\hline Odesa & 0.604 & Odesa & 13.2 & Zaporizhzhya & 42.4 \\
\hline Zaporizhzhya & 0.586 & Mykolayiv & 12.8 & Luhansk & 44.0 \\
\hline Dnipropetrovsk & 0.583 & Donetsk & 12.1 & Donetsk & 44.1 \\
\hline Donetsk & 0.582 & Zaporizhzhya & 7.2 & Odesa & 44.3 \\
\hline Kherson & 0.579 & Luhansk & 6.1 & Mykolayiv & 45.8 \\
\hline Kirovohrad & 0.554 & Kirovohrad & 1.0 & Kharkiv & 47.9 \\
\hline Poltava & 0.545 & Kharkiv & 0.2 & Dnipropetrovsk & 48.4 \\
\hline Kharkiv & 0.505 & Poltava & 0.2 & Kherson & 49.2 \\
\hline Average: & $0.602 \pm 0.001$ & Total: & 100.0 & Average: & $43.9 \pm 0.3$ \\
\hline
\end{tabular}

Dnipropetrovsk (48.4) and Kharkiv (47.9), where extensive irrigation schemes and agroindustrial development may be detrimental.

\section{Conclusions}

Because D.caspius is an ectotherm, temperature (at least theoretically) should heavily influence its development, behaviour and physiology, however ecological niche modeling found a strong influence of precipitation (in the first place) and temperature (in the second). Of course, this may be due to the scale of the study, because model quality depends not only on the algorithm, but also on the measure of model fit used and the scale at which it is used. Nevertheless, this finding is consistent with findings reported by other authors. For D. caspius we found a strong East-West variation related to variables associated with precipitation, true for the entire home range of the species.

Although the modeling algorithm Maxent is prone to overfitting [21], particularly when "too many" variables are incorporated into the model, the best performing model was the one with the full set of bioclimatic variables (AUC >0.9).

According to the modeling excercise, $22 \%$ of the area in Ukraine and the Crimea is predicted to be highly suitable for the snake. Some of these are marginal for the species, so any recordings would be important for tracking consequences of climate change.

Taking into account human impact, important administrative units for preserving D. caspius in the study area can be defined by averaging the ranks presented in Table 2: Crimea (10.3) $>$ Mykolayiv (7.3) $>$ Odesa (7.0) $>$ Luhansk (6.7) $=$ Zaporizhzhya (6.7) $>$ Dnipropetrovsk (6.0) > Donetsk (5.7) $>$ Kherson (4.7). Kirovohrad, Poltava and Kharkiv units could be important for accommodating marginal populations.

\section{References}

1. Sindaco R., Venchi A., Grieco C. The Reptiles of the Western Palearctic, Volume 2: Annotated Checklist and Distributional Atlas of the Snakes of Europe, North Africa, Middle East and Central Asia. Latina, Edizioni Belvedere, 2013. 544 p. 
2. Covaciu-Marcov S.-D., David A. Dolichophis caspius (Serpentes: Colubridae) in Romania: New distribution records from the northern limit of its range. Turkish Journal of Zoology, 2010, vol. 34, pp. 119-121.

3. Red Data book of Ukraine. Animals. Ed. by I. A. Akimov. Kyiv, 2009. 600 p. Available at: http://redbookua.org/ru (accessed 13.05.2016).

4. Red Data Book of the Russian Federation (animals). RAN Vol. I. Danilov-Danilyan, etc. Moscow, AST Publ., Astrel' Publ., 2001. 862 p. Available at: https://www.mnr.gov.ru/upload/iblock/7ce/krasnaja_kniga\%20 givotnie1.zip (accessed 13.05.2016).

5. Research Fronts. 100 Top Ranked Specialties in the Sciences and Social Sciences. Compiled by Thompson Reuters in cooperation with the National Science Laboratory, Chinese Academy of Sciences (NSCL). Annual report. 2014. 62 p.

6. Phillips S. J., Anderson R. P., Schapire R. E. Maximum entropy modeling of species geographic distributions. Ecological Modeling, 2006, vol. 190, no. 3-4, pp. 231-259.

7. Elith J., Graham C.H., Anderson, R.P. et al. Novel methods improve prediction of species' distributions from occurrence data. Ecography, 2006, vol.29, no. 2, pp. 129-151.

8. Duan R. Y., Kong X. Q., Huang M. Y. et al. The predictive performance and stability of six species distribution models. PLoS One, 2014, Nov. 10, vol. 9, No. 11, pp. e112764.

9. Sahlean T. C., Gherghel I., Papeş M., Strugariu A., Zamfirescu Ş. R. Refining Climate Change Projections for Organisms with Low Dispersal Abilities: A Case Study of the Caspian Whip Snake. 2014. PLoS ONE 9(3): e91994.

10. Dotsenko I. B. Catalogue of collections of the Zoological Museum of the NSNHM, NAS of Ukraine. The Snakes. Kiev, NSNHM, 2003. 86 p.

11. Biliakov I. V., Tarashchuk S. V. For distribution in North-West black sea region of some species of snakes that are under special protection in Ukraine. Registration of animals under Red Data Book of Ukraine. Ed. by A. V. Kostiushin. Kiev, 2008, pp. 9-16.

12. Kotenko T. I., Kurjachii K. V. Finds of reptilian species that are proposed for inclusion in III edition of Red Data Book of Ukraine, in Donetsk oblast - Ukrainian. Registration of animals under Red Data Book of Ukraine. Ed. by A. V. Kostiushin, Kiev, 2008, pp. 152-170.

13. Verbruggen H., Tyberghein L., Belton G. S. et al. Improving transferability of introduced species' distribution models: new tools to forecast the spread of a highly invasive seaweed. PLoS One, 2013. 8: e68337.

14. Hijmans R. J., Cameron S. E., Parra J. L. et al. Very high resolution interpolated climate surfaces for global land areas. International Journal of Climatology, 2005, vol. 25, no. 15, pp. 1965-1978.

15. Swets K. Measuring the accuracy of diagnostic systems. Science, 1988, vol. 240, pp. 1285-1293.

16. Wildlife Conservation Society (WCS), and Center for International Earth Science Information Network (CIESIN). Columbia University. Last of the Wild Project, Version 2, 2005 (LWP-2): Global Human Footprint Dataset (Geographic). 2005. NASA Socioeconomic Data and Applications Center (SEDAC), Palisades, New York. Available at: http://sedac.ciesin.columbia.edu/data/set/wildareas-v2-human-footprint-geographic (accessed 18.03.2015).

17. Owen J. G., Dixon J. R. An ecogeographic analysis of the herpetofauna of Texas. Southwestern Naturalist, 1989, vol.34, no.2, pp. 165-180.

18. Ward R., Zimmerman E. G., King T.L. Environmental correlates to terrestrial reptilian distributions in Texas. Texas Journal of Science, 1994, vol.46, no. 1, pp. 21-26.

19. Elith J., Phillips S. J., Hastie T. et al. A statistical explanation of MaxEnt for ecologists. Diversity and Distributions, 2011, vol. 17, no. 1, pp. 43-57.

20. Parmesan C., Yohe G. A globally coherent fingerprint of climate change impacts across natural systems. Nature, 2003, vol. 421, no. 6918, pp. 37-42.

21. Baldwin R. A. Use of maximum entropy modeling in wildlife research. Entropy, 2009, vol. 11, no. 4. P. 854-866.

For citation: Tytar V.M., Nekrasova O.D. Species distribution modeling of the Caspian whipsnake Dolichophis caspius (Squamata: Serpentes): a tool for ranking conservation priorities in the Western Pontic steppe. Vestnik of Saint Petersburg University. Series 3. Biology, 2016, issue 3, pp. 144-149. DOI: $10.21638 / 11701 /$ spbu03.2016.324

Статья поступила в редакцию 13 января 2016 г., принята 10 мая 2016 г.

Authors information:

Tytar Vladimir M. - PhD, Senior Researcher

Nekrasova Oksana D. - PhD, Senior Researcher 